\title{
Study on the Teaching Mode of Combining Self- study Examination with Skill Training for Art Design
}

\author{
Jijuan Zhang \\ School of Furniture and Art Design \\ Central South University of Forestry and Technology \\ Changsha, China \\ e-mail: csfujuan@163.com
}

\author{
Jia Lu \\ School of Extended Education \\ Central South University of Forestry and Technology \\ Changsha, China \\ e-mail: csfujj@163.com
}

\begin{abstract}
Art Design is a practice-based disciplines, the goal of its self-study examination should be to train the applied talents who engage in the practical work in first-line. To achieve training objectives, it is necessary to explore a new teaching mode of combining self-study examination with skill training for art design. Paper discusses the new teaching reform from the changing of teaching concepts, reform of examination system, the clear positioning of self-study examination teaching materials, strengthening the combination of practice teaching and professional skills training, etc. This is consist with the current direction of higher education to training skilled personnel, also has a very important practical significance.
\end{abstract}

Keywords-Art Design; Self-study examination; Skill Training; Teaching Reform

\section{INTRODUCTION}

Self-study examination is an important supplement form of higher education, in recent years, the students are increasingly centralized and younger, and the work has been facing unprecedented changes. Which has derived the counseling of full-time and network from the traditional form of amateur counseling suitable for the working candidates. The full-time students can enjoy the college campus atmosphere and get social recognition, especially for vocational students, which is an ideal choice for them. Many institutions actively carry out various full-time counseling using the ample teaching resources, and the scale of self-study examination has experienced unprecedented prosperity [1]. But these young candidates are not just to pass the examination and solve diplomas problems, at the same time, it is more important to solve their employment through skills training. Thus the reform of self-study examination should meet the social demand for talent, especially the training direction of professional skills, must adapt to the current employment situation and the demand for talent. In order to ensure sustainable development of self-study examination, it is necessary to comprehensive analyze the characteristics of students, and explore the suitable teaching mode of combining self-study examination counseling with the professional skills training, which can ensure students not only learn the basic theoretical knowledge but the professional skills, and reduce the duplication and waste of the teaching resources .
Art design is a practice-based disciplines, and its creativity and practicality is the most important. So the objective of art design self-study examination is to training applied talents, strengthening their innovation and practical ability, highlighting engineering training. The major of "Furniture and Interior Design" should train the professional skilled personnel who master the method of interior design, the drawing of renderings, material budget and construction skills. To achieve the above training objectives, it is necessary to explore a new art design teaching mode of combining self-study examination with skills training.

\section{CHANGING TEACHING IDEAS, AVOID MISUNDERSTANDING OF THE PASS RATE IS KING}

Now the source of self-study examination student is highly competitive, in order to ensure the pass rate, many schools often use the method of examination-oriented education. Such as centers on exams tactics, the class doesn't emphasize on the core idea and the relation of knowledge points, but spend a lot of time to explain how this knowledge is easy to test and how to answer the questions [3]. This teaching mode is unidirectional transfer of knowledge based on the teacher's lecture, which can spread a lot of knowledge in the limited time, but the students will be completely passive, that neither fully mobilize student's interest in learning, nor train the ability of students to think independently. In addition, many students' have lower educational structure, poor foundation, incorrect learning attitude. Even some students just to get a diplomas, there is no interest in learning, another part of students think that is too difficult to graduate, they are no confidence, certainly affect the other students' learning enthusiasm. Students all focus on the last review in order to pass the exam, the teaching is disordered, even many students cannot insist on finishing all subjects, that not only failed to keep students, but forming a vicious cycle. Now, the training goal of art design should be employment-oriented to train application-oriented highly skilled personnel. The teaching ideas should transform simply focus on students' mastery of knowledge to knowledge and ability emphasized both. To meet this requirement, it is necessary to change the traditional teaching mode of self-study examination, reform and innovative the teaching methods. 
Many students of self-study examination have poor foundation and learning enthusiasm, in response to this situation, the teaching should emphasize on the understanding to memory, make them study easily and have the sense of accomplishment. The arrangement of course should be gradual follow the rules of teaching, but not completely in accordance with the examination order. The teaching and learning of one course is required to master its pilot courses relevant knowledge. Such as the pilot course residential interior design and furniture design are the design drawing and interior decoration materials, the degree of students master foundation course will influence the professional course learning effect.

Compared with the regular graduates, the students of selfstudy examination will be at a disadvantage state when they participate in social competition. So the teaching management should strengthen the guidance and encouragement to help them analyzing their superiority and disadvantage, correctly understand the significance of self-study examination, and establish confidence. They can get a diploma through selfstudy examination to compensate for the lack of college exam, greatly increase the competitiveness of expertise. In addition, the candidates with the self-study exam diploma should be confident, they passed the very strict national examination and have the quality of brave enterprising. At the same time, it is necessary to strengthen the management of teaching order, and urge students to strictly observe classroom attendance system, to develop their good study habits.

\section{REFORMING THE CURRENT EVALUATION SYSTEM}

The current evaluation system of self-study examination focuses on a single theoretical examination. However, the theory of professional courses for art design has more emotional component, diction terminology is not unique, and some strange questions are often asked on the test paper. Even the phenomenon of scrape together the number of questions is often existed in order to pursue the amount and diversification of the test paper, or the duplicate and inane questions in the same paper. Of course, the reasonable and adequate theory test can help students to understand the basic knowledge and concepts, improve their practical ability. However, once the test becomes only a form, the examination will lose its true meaning, and also bring some negative effects.

The students' ability of analyzing and solving problems is more important for art design, in order to achieve the teaching purpose, the multi-angle test should be held. Therefore, the course of art design should evaluate both the theoretical and practical examination, theory test should be appropriate. Because the role of theory is to strengthen practical ability, it is not conducive to reflect theoretical guidance function if separate to account the academic results, that students will remember the theory for examinations, and weaken the training of professional skills. The theoretical examination should emphasis on the basic knowledge, at the same time we also should pay attention to the improvement of practice ability. Originally vibrant art design must not be stiff rigid due to the examination manacled its clever design thinking. Furthermore, appropriate increasing the examination content and proportion of practice course, then it can test the candidate's ability level, and lay a good foundation for engaging in appropriate career.
In recent years, Hunan province self-study examination higher education of art design is more close to the subject characteristics, the type and amount of question is relatively reasonable, theory and practice in the same paper, theory test scores accounted for only a small part. These papers not only make test designers enough to consider and select the theory test, but also test the examinee's true skill and genuine knowledge from the practice. It is a good method for comprehensive evaluating the ability of the examination candidates of art design. Meanwhile, that can avoid test designers to make up the numbers of exam questions, the inappropriate test question will also be less. This measure provides a good reference for others practice subject to study out the way of self, it is worth learning.

\section{ESTABLISH THE TEACHING MATERIALS SYSTEM WITH A CLEAR POSITIONING}

As we all know, in order to facilitate students can be more systematic study the theoretical knowledge of a subject, examiner department would specify the appropriate reference for tests subjects, the theoretical questions of self-study examination are basically selected from the specified reference. But art design is more perceptual, and its performance practice and technique is rich and varied, narrative language is broad, then once taken the specified reference as the examination questions standard answer, sometimes there will be a number of defects. For example, it often occurs that some questions in the paper are not standardized and rigorous. Although the reference is selected by examiner department with several screening, but because of the particularity of art design discipline, the selected reference and exam questions are often less than satisfactory.

On the other hand, because the absence of specialized teaching materials for self-study examination, and now a lot of reference books commonly selected from college textbooks, its readers are full-time studying college students, they have a good environment for professional theory learning and practical ability training which is more standardized and systematic. But the students of self-study examination have poor foundation, and to self-oriented, they are different from the ordinary college students on acquiring the emphasis of specialized knowledge and ability training mode. Therefore, the teaching materials of self-study examination should reflect the characteristics of discipline and appropriate positioning. Examiner department should organize relevant professional teachers to develop new teaching materials, and establish the system of textbooks with clear professional characteristics. Especially the textbooks of practice-based courses should write for improving the ability of practical application, and conform to the purpose of self-study examination.

\section{TEACHING REFORM OF COMBINING SELF-STUDY EXAMINATION WITH SKILLS TRAINING}

The teaching program of combining self-study examination with skills training is in line with the current direction of teaching reform, which can provide new ideas to further improve the personnel training of self-study examination. But 
this teaching reform must be beyond the traditional confines of self-examination, it is necessary to make student individualized, meet their wishes, guiding them to choose the learning degree of combining academic education with skills training, and to systematic reform the teaching programs and the test methods.

\section{A. Reasonable position of teaching programs}

The self-study exam is a supplement to the form of higher education, so far the pass rate of self-study exam is very low and the cultivation of professional skills is almost in a blank. The teaching program of combining self-study examination with skills training should be rationalize, it is not to ask all students achieved good results in the self-study examination and skills training, but to let them have a selection for different students. For example, the good students will both pass the self-study examination and improve professional skills, some poor foundation students will get the appropriate profession certificates, at the same time, they can also achieve the effect of expanding professional knowledge.

\section{B. Employment-oriented, defining the basic skills of art design}

It is the key of self-study examination teaching reform that the direction of professional skills is reasonable, whether make students to master the appropriate professional skills. The courses must ensure the reasonable proportion of basic professional skills and professional theories. Graduates of art design will always use graphics software in the actual work, they must be familiar with the practical design and construction techniques. So the teaching program of art design must highlight the proportion of practical teaching, strengthen the actual drawing skills training, meet the requirements of interior designers permits and other skills training to organize teaching, in order to improve the employability of students.

Therefore, students can choose the following certificate after they complete the study course and pass the examination: (1) The international certification of American Autodesk, This certificate is a testament of AutoCAD drawing application ability, it is drawing software certification. (2)The certificate of interior designer issued by national department of labor and social security, this certificate is the requirements for design staff, which is the credential for various enterprises and institutions.

\section{Strengthening practical teaching, combining the professional skills training}

In connection with the current deficiencies of self-study examination tests system, combining with the practical characteristics of art design, it is necessary to reduce the difficulty of theory content and the examination curriculum subjects, significantly improve the proportion of practical teaching and assessment, which can strengthen professional skills training, in order to make the entire teaching plan is more reasonable. So the practical teaching must be clear objectives and direction, focus on professional features to truly organic combine the academic education and skills training. For example, there are 10 professional courses in art design self-study examination, we can combine the theory and practice contents of the curriculum, and then build up the practice content and skills assessment project, which can reduce the difficulty of theory knowledge, while make the teaching of practical course to be clear direction. As shown in "Table I."

TABLE I. THE GOAL POSITIONING OF ART DESIGN PROFESSIONAL PRACTICE TEACHING

\begin{tabular}{|c|c|c|}
\hline Theory Course & $\begin{array}{c}\text { Project of practice } \\
\text { teaching }\end{array}$ & $\begin{array}{c}\text { Requirements } \\
\text { of professional } \\
\text { skills } \\
\end{array}$ \\
\hline Sketch, color & Hand painted & \multirow{2}{*}{$\begin{array}{l}\text { Senior drafters } \\
\text { certification }\end{array}$} \\
\hline CAD、3D、PS & Design software & \\
\hline $\begin{array}{l}\text { Interior decoration } \\
\text { materials, } \\
\text { Decoration budget }\end{array}$ & $\begin{array}{l}\text { Cognition practice of } \\
\text { furniture and interior } \\
\text { decoration materials }\end{array}$ & \multirow{3}{*}{$\begin{array}{l}\text { "Interior } \\
\text { designer" } \\
\text { national } \\
\text { occupation } \\
\text { qualification } \\
\text { certification }\end{array}$} \\
\hline $\begin{array}{c}\text { Principle of interior } \\
\text { design, } \\
\text { Interior design }\end{array}$ & Interior design practice & \\
\hline $\begin{array}{l}\text { Interior style and } \\
\text { genre, } \\
\text { Interior space design, } \\
\text { Interior furnishings } \\
\text { design }\end{array}$ & $\begin{array}{l}\text { Professional cognition } \\
\text { practice of in } \\
\text { terior environmental } \\
\text { design }\end{array}$ & \\
\hline $\begin{array}{c}\text { Furniture design, } \\
\text { Furniture production } \\
\text { process }\end{array}$ & $\begin{array}{c}\text { Furniture factory } \\
\text { practice }\end{array}$ & $\begin{array}{l}\text { Furniture } \\
\text { designer } \\
\text { certification }\end{array}$ \\
\hline
\end{tabular}

The teaching program of combining self-study exam with skills training will reduce the test courses and lower the difficulty of theoretical courses, which is based on the principle of "enough for the using" to learn the theoretical content. The pass rates is not the single purpose of self-study examination, it is more important to make themselves both understanding the professional theoretical knowledge, but also mastering the basic professional skills, which can enhance cultural awareness while improve employability and employment rates, and better serve the society[5].

In addition, during the process of teaching reform, it is also need to strengthen the management of daily teaching, guide students to master good method of learning, correct learning attitude, and constantly improve the learning enthusiasm. At the same time, creating a good learning atmosphere, such as increasing the coaching of self-study at night, strengthening skill training, and changing the students bad learning habits, increasing their learning time and promoting the improvement of teaching quality.

\section{CONCLUSION}

The teaching program of combining self-study examination with skills training is the inevitable trend of higher education reform. It is in line with the current direction of higher education to training skilled personnel. It is also having a very important practical significance, that truly combined professional skills training with self-study examination, and linked up the enhancing of comprehensive cultural quality of young labors who has poor education and professional skills training, which can avoid the repetition of labor employment training, and relieve the stress of national labors training, 
promote the improvement of employability and social stable development.

\section{ACKNOWLEDGMENT}

It is supported by the Educational Reform Research Program of Hunan Province (No.2013-197), and the Educational Reform Research Program of Central South University of Forestry and Technology (No.2012-5).

\section{REFERENCES}

[1] XIA Huiyun and LU Junbo, "Study on the innovative training mode of higher education self-study examination in the new situation," Journal of Yunnan Agricultural University, vol.5, 2011, pp. 78-80,84.

[2] CHEN Junhong, "Discuss on the position of practical disciplines from the art design self-study examination," Monthly of Education Research, vol.9, 2009, pp. 72-73.

[3] LIU Ningning, "How to improve the pass rate of higher education selfstudy examination," Northern Literature, vol.8, 2012, pp. 174-175.

[4] XING Xiao, "Research and practice of the teaching program of combining self-study examination with skills training- take Zhejiang Vocational college classes in Case," Vocational Education Forum, vol.17,2012, pp. 36-37.

[5] DONG Yiping, "Research on both Academic and Vocational Education simultaneously in Higher education self-study examination," China Adult Education, vol.9,2009, pp. 23-24. 
